\title{
Ideological Differences in the Sino-Ethiopian Relations from the Early 1950s to the Late 1960s
}

\author{
Betelhem Tirusew Bayu \\ Research School for Southeast Asian Studies, Xiamen University, Xiamen, China \\ Email: betelhemenete@stu.xmu.edu.cn
}

How to cite this paper: Bayu, B. T. (2022). Ideological Differences in the Sino-Ethiopian Relations from the Early 1950s to the Late 1960s. Open Journal of Political Science, 12, 125-143.

https://doi.org/10.4236/ojps.2022.122008

Received: January 10, 2022

Accepted: February 18, 2022

Published: February 21, 2022

Copyright (อ 2022 by author(s) and Scientific Research Publishing Inc. This work is licensed under the Creative Commons Attribution International License (CC BY 4.0).

http://creativecommons.org/licenses/by/4.0/ (c) (i) Open Access

\begin{abstract}
Ethiopia and China have built strategic diplomatic relations over the last three decades. However, before growing to build arguably one of the most fruitful diplomatic relations of the twentieth century, the diplomatic relations between the world's second-biggest economy and the country with the fastest economic growth in Africa knew a "dark" period between the 1950s going through the late 1960s. Incidentally, that was when China established fruitful diplomatic relations with many African countries. The present study analyzes the foreign policy model put in place by the then Ethiopian Emperor Haile Selassie, a model established from the 1940s, solidified in the 1950s going until the decay of Haile Selassie's hegemony in the late 1960s, and how this model did not fit the model adopted by their Chinese counterpart. The foreign policy implemented by China from the 1950s was incongruent with Haile Selassie's dream for Ethiopia's modernization inspired by the capitalists of the West. The paper examines the dynamics of the Sino-Ethiopian relations during the period that both China and Ethiopia strived to gain international recognition and explores the reasons that hindered China and Ethiopia from building fruitful diplomatic relations. From the perspective of the history of the Sino-Ethiopian diplomatic relations, the paper analyses the current state of the Sino-Ethiopian relations in Ethiopia under conflict.
\end{abstract}

\section{Keywords}

Sino-Ethiopian Relations, Ethiopia under Haile Selassie, China in Africa (1950-1960), Ethiopia Sociopolitical Unrest

\section{Introduction}

One aspect that has marked the uprising to China becoming the world's second largest economy is the intensification of the relations between the Asian giant 
and African countries. The Sino-Africa exchanges have witnessed remarkable progress in all spheres. China is Africa's biggest partner today. In the last three decades or so, based on principles of brotherliness, China has prioritized its relationship with African countries and engaged with her African brothers proactively. In the last 30 years, "China has made it a tradition that its foreign minister

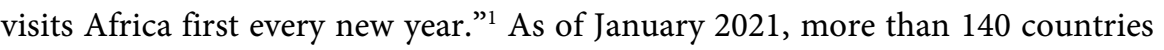
had joined China's multi-billion Belt and Road Initiative. Among these, 48 are African countries. ${ }^{2}$ According to Adunbi and Stein (2019: p. 193), one significant aspect that has propelled the relationship between China and Africa is China's "'Going Out' policy." The Forum on China-Africa Cooperation (FOCAC), established in 2000, is one platform that has facilitated the bilateral exchanges between China and Africa. At the III Forum on China-Africa Co-operation (FOCAC), held on 3-4 September 2018, the development of Africa was at the top of the agenda. At the end of the conference, China placed at Africa's disposal a fund estimated at USD60.000 million to help the African counties to build a "prosperous Africa" (Chemane, 2019: p. 71). Among the African countries, Ethiopia is one of the key partners of the Asian giant. In recent years, the bilateral relations between China and Ethiopia have known a significant growth, and, for example, China is currently Ethiopia's top import and export partner.

Many works in the literature point that Ethiopia and China established formal diplomatic relationships around the 1970s (Shinn, 2014). However, it is important to note that the Sino-Ethiopia ties had been a top priority for China's new government under the leadership of Mao Zedong in 1949. However, the Sino-Ethiopian relation went through a difficult period between the 1950s to the late 1960s. This situation would come to change in mid-1970s, a period during which the relations between the two countries began to gain a new shape before being firmly cemented in the early 1990s. This paper aims to analyze the Sino-Ethiopia relation between the 1950s to the late 1960s, a period marked by important changes in Africa and China. Two questions motivate the present investigation: 1) What factors hindered the development of productive relations between China and Ethiopia from the 1950s to late 1960s? 2) How these two countries were able to shake off the pressure by the Western powers and the Soviet Union to become key partners in the early 1970s?

The Sino-Ethiopian relations between the period under investigation are generally understudied in the literature (but see Meskela and Zhang, 2009: pp. 29-32, for a brief overview of the Sino-Ethiopian contacts in the period between 1940 and 1970). Therefore the objective of the present effort is to close the gap in the study of Sino-Ethiopian relations in the mid-twentieth century. The paper is divided as follows: the second section presents a brief review of the general panorama of China and Ethiopia's engagement in international relations. Section

${ }^{1}$ Dickens Olewe, "Why African countries back China on human rights," BBC News, May 2, 2021, https://www.bbc.com/news/world-africa-56717986.

"Countries of the Belt and Road Initiative (BRI)," by Green finance and development center, accessed on November 6, 2021 https://greenfdc.org/countries-of-the-belt-and-road-initiative-bri/. 
three describes China's shift in its foreign policy in the late 1950s and early 1960s. Section four delves deeper into the history of China and Ethiopia's international relations in the context of the Cold War, focusing specifically on the period between the 1950s to the late 1960s. It first describes how China and Ethiopia met in the international relations stage, especially during the Korean War, where the two countries met from opposing sides. Section five describes how the Sino-Ethiopian relations began to gain shape. The section presents a brief discussion on how Ethiopia disentangled itself from the West to finally recognize China, paving the way for establishing diplomatic relations that have been producing unprecedented results up to the present day. Section six seeks to put the history of the relation between China and Ethiopia in perspective of the current situation in Ethiopia. Finally, a brief conclusion is provided in the closing section.

\section{Sino-Ethiopian Relations in Perspective}

The first contact between the People's Republic of China (PRC)'s leaders and the Ethiopian leaders can be traced to the mid-1950s when the Chinese Premier Zhou Enlai met Ethiopia's Emperor at the Bandung Conference in 1955. The two leaders would meet again when Zhou Enlai visited Africa from 1963 to 1964. In this period, Premier Zhou Enlai visited ten African countries (Muekalia, 2004), including Ethiopia (Niu, 2010). ${ }^{3}$ Venkataraman and Gamora (2009) argue that the bilateral relations between China and Ethiopia can be highlighted in three distinct phases, from the period of the foundation of the PRC under the leadership of the Mao Zedong in 1949 to the late 1970s; China's period under Deng Xiaoping's leadership (1977-1990) and the post-Cold War era to the present. While the relationships between the two countries over these three distinct periods have been marked by increasing and steady development, it was not until the second period going through the third that China and Ethiopia's strategic partnership gained the momentum that characterizes the diplomatic relations between the two countries today.

With the outbreak of the Cold War in the early 1950s, right after World War II, the capitalist allies of the West and the communist of the East, with the U.S. and the Soviet Union as ideological opposites, tried to convert developing countries to their respective sides. Having aligned with the Soviet Union, China shortly saw herself forced to choose the path of non-alignment and subsequently the path of isolation. The clash of ideologies between the Chinese leadership and the Soviet-Union leadership undermined the Sino-Soviet relations, and with the split, China sought to strengthen its influence on African countries and other Asian countries.

Meanwhile, Ethiopia remained the only African country that was not under colonial domination. Under the leadership of Haile Selassie, Ethiopia engaged

${ }^{3}$ During the visit, Zhou Enlai presented to the African leaders the two pillars on which the China-Africa relations would hinge on going forward, namely the "Five Principles Governing the Development of Relations with Arab and African Countries" and "Eight Principles for Economic Aid and Technical Assistance to Other Countries” (Hanauer \& Morris, 2014: p. 19). 
actively in creating an atmosphere of a united Africa. Haile Selassie presided over the formation of the organization of African Unity, later African Union, and became the first chairman of that organization. Under Haile Selassie, Ethiopia was one of the four African countries that sent their delegation to the 1945 San Francisco Conference on International Organization, and Ethiopia became a charter member of the United Nations. ${ }^{4}$

China was prompted to ally with the Soviet Union hoping to maintain a status of an equal partner. One of the reasons that led to the deterioration of the Sino-Soviet alliance was the reluctance of China into accepting the relationship of "leading (the Soviet Union) and being-led (China)" (Niu, 2005), a position that China had accepted when it suited her interests. As China's influence in the international sphere intensified, Mao's government could no longer maintain the relationship of leading and being-led that had been crucial to the two countries coming together (Luan, 2007: p. 34, see, for example, Niu, 2005). With the Sino-Soviet split, China's diplomatic agenda shifted to intensifying the bilateral relation with African countries and other Asian countries. While seeking to cement China's central position in the international community (see Li, 2011; Chen, 2019), China would eventually identify itself as a Third World country. For Africa, China emerged as an important partner with a strong sense of ideological affinity. China placed the resolution of conflict borders with Asian countries and providing assistance to African countries in their liberation struggles as top priorities in their foreign policy agenda.

As already mentioned, the first formal contact between China's new government and African countries was established in 1955's Bandung Conference (see Traoré, 2021). On this occasion, the Chinese Premier Zhou Enlai met with the representatives of six African countries (Egypt, Ethiopia, Ghana, Liberia, Libya, and Sudan). China's engagement with African countries was based on a clearly delineated political agenda: to cope with the Cold War superpowers. From China's point of view, attaining international recognition could only be achieved through its diplomatic robustness in the competition between the U.S. and the Soviet Union. Compared to the U.S. and Soviet Union, China stood up by its historical affinities with Africa: both China and Africa fell under the oppression by capitalists and imperialists; and thus shared the same struggles to liberate themselves from these powers (Liao, 2013: pp. 40-41).

As far as the destiny of the African countries' liberation from their European masters was concerned, China and Ethiopia shared a common goal. Moreover, Ethiopia's importance as a strategic partner to China in supporting African countries' liberation fight was paramount. In short, a brief look at the history of the engagement of China and Ethiopia at the international level, especially with African countries, from the early 1950s onwards, should suggest that China and Ethiopia had all the conditions to develop productive diplomatic relations. However, the Sino-Ethiopia relations did not thrive, as China and Ethiopia faced

${ }^{4}$ United Nation Official Page, "Was Africa represented during the 1945 San Francisco Conference on International Organization?” November 7, 2021, https://ask.un.org/faq/199031. 
many barriers that hindered them from forging productive diplomatic relations. Ethiopia and China could not build upon the first contacts established between the Chinese Premier and the Ethiopian Emperor during the Bandung Conference to pave the way to establishing diplomatic relations. And later, when the Chinese Premier visited Ethiopia, the Sino-Ethiopian relations were not immediately established either, even though China was able to establish diplomatic relations with many African countries during this period. In what follows, we will examine what factors undermined Chinese efforts to establish fruitful diplomatic relations with Ethiopia from the mid-1950s to late 1960s.

\section{China's Foreign Policy Shift in the Late 1950s and Early 1960s}

To understand the relations between China and African countries, in general, and how China and Ethiopia met at the international stage, in particular, it is important to describe China's foreign policy shift in the late 1950s and early 1960s.

China's alliance with the Soviet Union was catalytic in shaping China's foreign relations in the 1950s. When the split became inevitable, and both nations parted ways in the early 1960s, China had to make profound adjustments in its foreign policies, most of which were motivated by China's domestic situation (Niu, 2005; Li, 2011). With pressure from the U.S. and Soviet Union, China shifted its foreign policy to seek closer ties with Asian and African countries. In 1954, in an attempt to create an atmosphere of universal peace, China adopted the "Five Peaceful Co-existence Principles." China's pro-activeness in maintaining "Peaceful Co-existence" was soon materialized with Beijing's efforts to solve the border problems with the surrounding Asian countries. Meanwhile, African countries were also engaged in their liberation struggles. China's identification with Third World countries and its belief in the possibility of living in a peaceful world saw China increasingly involved in the struggle of African countries.

Extending its influence from Asia to Africa meant that China was moving from a regional power to a world power. At that time, with its policy of "non-interference," China represented a better option to many African countries than the West and the Soviet Union, whose support came with interference in domestic affairs of the target country. To shake the pressure created by the Soviet split and the pressure by the U.S., Mao's government needed to extend its influence abroad, especially in Africa. China's efforts to establish long-lasting ties with Africa were rewarded, and China's influence in Africa became ever-increasing. After the Asian-Africa Conference in 1955, the political ties between China and an increasing number of African countries that had become independent were significantly cemented. By 1965, 19 African nations had officially established bilateral relations with China. ${ }^{5}$ Later in 1971 , with the $26^{\text {th }}$ ses-

\footnotetext{
${ }^{5} \mathrm{Han}$ Lin \& Meng Tao, "70 years of diplomacy: How PR China claimed its lawful seat in the UN," China Global Television Network, September 24, 2019,

https://news.cgtn.com/news/2019-09-24/70-years-of-diplomacy-How-PR-China-claimed-its-lawful -seat-in-the-UN-KeWvvlhrLa/index.html.
} 
sion of the United Nations General Assembly, among the developing countries that voted for China's return to the United Nations, the African countries were the majority (Niu, 2018: p. 67). Since the early 1960s, China has advanced its influence in Africa by resorting to full-scale political, economic, military, cultural, and educational ties (Shinn, 2005).

From China's point of view, supporting the liberation struggles of African States, hence expanding its scope of influence, was key to China carving itself into becoming a world power. On the other hand, African countries were in dire need of external support, and as they were entering a post-independent phase, African countries needed to guarantee their politico-economic reconstruction (Leake, 2020). China provided the much-needed support for the African countries' liberation struggles and actively helped in the process of reconstruction for many African countries post-independence. A good example of China's involvement in the reconstruction of African' countries after independence is the construction of the Tanzania-Zambia railway (see Traoré, 2021: p. 616). In such a background, one would expect to see China and Ethiopia forging positive relations. After all, the Ethiopian Emperor was also engaged in seeing a free and united Africa. However, as demonstrated in the next section, that was not the case. On the contrary, China and Ethiopia would often meet on opposite sides.

\section{Sino-Ethiopian Contacts from the 1950 s to the Late 1960 s}

China's advances to establish diplomatic relations with African countries were very positive during the 1950s. During this period, China established ties with important figures involved in the African liberalization movements. Such one figure is the Ghanaian leader Kwame Nkrumah, "the father of African nationalism" (Birmingham, 1998). Ghana joined the hosts of Algeria, Egypt, Guinea, Somalia, Morocco, and Sudan that had already been engaging with China. Nkrumah was a strong "activist" for a united Africa, which, as already mentioned, was also Haile Selassie's dream. Nkrumah actively sought to see a united Africa. He was quoted to have stated that the independence of Ghana "would become meaningful only in the context of Africa's total liberation" (Agyeman, 1992: p. 38). However, unlike Nkrumah, whose affinities with China, besides actively supporting the African countries struggles, included the fact that both Nkrumah's and Mao's governments championed the vision of world peace, and the two adopted socialist governments, Haile Selassie was a capitalist. Ideological differences would hinder China's attempts to establish diplomatic relations with its most important bilateral economic partner in Africa, Ethiopia, during the 1950s.

The question to ask at this juncture is what were the reasons for China and Ethiopia's failure to build positive diplomatic relations in a period when both countries so vigorously sought to make their impact felt in Africa and throughout the world? Certainly, it was not entirely due to ideological differences. Ethiopia is one of the first African countries to ever come in contact with China. This contact is dated from the Han dynasty between $202 \mathrm{BC}$ and $220 \mathrm{AD}$, where 
there are records of Chinese goods presumably reaching Meroe in northern Sudan. During this time, the Kingdom of Axum, present-day Ethiopia, is reported to have exported exotic products to China (Shinn, 2005: p. 1).

Moreover, China under Mao and Ethiopia under Selassie's foreign policy followed very similar paths. To a large extent, both Ethiopia and China's foreign policy model in the 1950s was driven by complex domestic and international factors at play during that time (Meskela \& Zhang, 2009: p. 32). Nevertheless, the similarities between Ethiopia and China were superficial though. And the differences were so profound that the two countries could not establish any productive diplomatic relations between the period from the mid-1950s to the late 1960s.

\subsection{China and Ethiopia Diplomacy in the 1950 s and 1960 s}

While China under Mao's leadership identified itself with the Third World countries and sought to strengthen its relations with the "oppressed" in Africa (as well as Asia, South America, and some European countries), Ethiopia under Selassie followed the opposite path. Haile Selassie's government was engaged in modernizing Ethiopia. It was with the industrialized West that Haile Selassie identified himself. He made efforts to build a government formed by educated cadres and avoided over-reliance on one outside country. He brought foreign advisers from France, Switzerland, the United States, the United Kingdom, and Greece (Vaughan, 2015: p. 289). His modernization targeted included, among other areas, education, the army, and commerce.

Haile Selassie ascended to power in 1930. By that time, his modernization agenda quickly took shape. His plans, however, would eventually be cut short by the invasion by the Fascist Italians. The days of the defeat at Adwa in 1896 were long gone when Italy, at the time relying on modernized weaponry, attacked Ethiopia in October 1935. Ethiopia surrendered to the Italians, who, on 5 May 1936, took control of Addis Ababa and established an "east African empire stretching from the Red Sea to the Indian Ocean" (Vaughan, 2015: p. 191). At this point, Haile Selassie was left with two options, die as a martyr or flee into exile. It was the latter option that the Emperor took. He fled to live in exile in a small town in England. During his time in England, Haile Selassie gained more influence at the international level. However, even though Haile Selassie would eventually gain sympathies from both France and England and later from the U.S., the Western superpower adopted a pragmatic approach in dealing with the situation with which Ethiopia was confronted.

When Haile Selassie arrived in Britain, he was not received as head of state, the British counterpart arranged no official receptions, and during his stay in Britain, the Emperor was never invited to the palace. On 30 June 1936, Haile Selassie left England to appear before the League assembly. His efforts on Geneva would only prompt the League to vote for import and export sanctions against Italy and nothing more. The sanctions did not have a substantial effect on Italy 
(Henze, 2000: p. 120). Two reasons prevented Britain and France from taking bold or firm measures against Italy. First, both Britain and France had colonies in Ethiopia's neighboring countries, and they had always been cautious of the effects of the victory in Adwa. They feared that Ethiopia's success in resisting Italy could inspire the countries under their domination to follow Ethiopia's example and offer resistance. Secondly, Britain and France feared a coalition between Italy and Germany. France and England feared open warfare and did not dare to provoke Mussolini. Faced with the European hesitancy and prevarication, Roosevelt, the president of the U.S., at that time, could do little to help Ethiopia's cause.

When Mussolini finally declared war on Britain and France on 10 June 1940, Britain retaliated by targeting Mussolini's "weak spot," his African Empire. Britain emerged victoriously and would eventually occupy the Africa Orientale Italiana. With the defeat, Italy was unable to maintain its occupied territory in northeast Africa (Henze, 2000: pp. 121-127). Not long after, the conditions were created for Haile Selassie, with the support of the British, to return to Ethiopia and resume his imperial duties, which he did on 5 May 1941.

While many countries were still under the yoke of colonization, Haile Selassie understood the uniqueness of his country as far as colonial domination was concerned. However, Haile Selassie was aware that if he was going to impose himself as a preeminent figure in Ethiopia and the whole African continent, it would be by the degree of his international influence in the European circle. Most crucially, the association with the Europeans was key to accomplishing Haile Selassie's plans of modernization and reform in Ethiopia. In the early 1920s, Haile Selassie made an advance to see Ethiopia becoming a League of Nations member, but Italy, who had lingering issues with Ethiopia, sought by all means to frustrate Selassie's aspirations to join the League. An issue that Haile Selassie was faced with was the fact that slavery was still a reality in Ethiopia. Critics pointed to this fact to underscore the fact that Ethiopia was unfit for the League. At first, Britain was among those who voiced criticism against Ethiopia, but the posture changed because they had interests (Henze, 2000: p. 200) in Ethiopia. Meanwhile, Haile Selassie was making efforts to eradicate slavery in the country. Effective measures to emancipate slavery and intensify control were successfully taken between May 1923 and April 1924. On 28 September 1923, in the final League debate, with the support of Britain and France, Ethiopia became a League of Nations member by unanimous vote, paving the way to Haile Selassie's active engagement with European countries that would follow (ibid).

It was the legacy and the prestige acquired during the 1920s and 1930s that China would eventually find in Haile Selassie's Ethiopia when Beijing shifted its foreign policy towards a more active partnership with Africa between the 1950s and 1960s. By 1960, though being under increase pressure domestically, Haile Selassie's reputation had grown to the extent that it could not be ignored in Africa's international relations.

In Africa, Haile Selassie "was a figure of a legend," and taking advantage of 
this growing fame, with Haile Selassie's reputation also grew Ethiopia's reputation as a fit continental leader. Materialistically, such position came to be accomplished with the Addis Ababa summit of African leaders in May 1963, which established the Organization of African Unity, to which Haile Selassie became the first chairman, and Addis Ababa its permanent headquarters, prompting Addis Ababa to become diplomatic capital of Africa (Clapham, 2015: pp. 202-203).

Such was Haile Selassie's influence in the heart of Africa's most notable leaders that Mandela described his first trip to Ethiopia in these terms:

"Ethiopia has always held a special place in my own imagination and the prospect of visiting Ethiopia attracted me more strongly than a trip to France, England and America combined. (...) Meeting the Emperor himself would be like shaking hands with history" (Jabulani, 2002: p. 172).

It is unlucky that China's relation with such an important figure for Africa would have been of little interest to Beijing. China's diplomatic relations between the 1950s and 1960s hinged directly or indirectly on the positive relationship they had built with the Soviet Union, and again to a large extent, the Sino-Soviet relations had been a cornerstone for Mao's government domestically. Mao's implementation of some domestic policies would come to hamper the rapid economic growth China sought to achieve after the foundation of the PRC in 1949. China's adoption of the "Five Peaceful Co-existence Principles" in 1954 was an important milestone in China's development of international relations. In 1955 a delegation of the PRC led by Zhou Enlai represented China at the Bandung conference (Wang, 1998). However, after a period of steady development of diplomatic relations, domestic and international events did not unfold in favor of China. Internally, the "mizhu zhengfeng" (the Democratic Consolidation of Spirits) in the spring of 1957, and the Great Leap Forward launched in 1958, two movements conceived with the intent to boost China's economy, to catch up with England and America's level of industrialization as quickly as possible (Yang, 2003) did not quite meet China's aspirations (Niu, 2005). Internationally, the severing of the Sino-Soviet alliance gradually became eminent. Under such circumstances, China had to readjust its foreign policy.

It goes without saying that China's alliance with the communist camp would always cause hindrances to a possible establishment of diplomatic relations between China and Ethiopia. After all, Haile Selassie would eventually forge an alliance with the Capitalist West with the modernized Western model that Haile Selassie so eagerly sought to emulate. With the advent of the Cold War, Ethiopia would eventually lean to the U.S. (a detailed explication of the complex relation between the U.S. and Ethiopia is given below).

\subsection{China and Ethiopia Meet on Opposite Sides}

At the end of World War II, the Korean peninsula was divided into two nations. The Soviet Union supported the northern part of Korea, while the southern was 
under the influence of the United States. In 1950, Northern Korea invaded Southern Korea resulting in the outbreak of the Korean war. With the support of the Soviet Union, the North was able to gain an advantage over the South. The U.S. mobilized a military offense composed by the United Nations contingents coming from over 21 countries. Haile Selassie also sent troops to Korea joining forces with the U.S. (Lyons, 1986). America and allied forces pushed Northern Korea back all the way across the $38^{\text {th }}$ parallel, up to the Yellow river causing a threat to China. In response, China engaged in support of North Korea, and the war was prolonged until 1953. The Korean War for Ethiopia and China meant that the two countries entered from opposing sides.

China entered the Korean War as a matter of national security threat. Nevertheless, it was still a bold decision because China was now engaging with the world's most powerful military. In the mid-1950s, the U.S. declared that the Taiwan problem was unsettled. As a result, China and U.S.'s long-lasting enmity was unleashed (Yang, 2003), an enmity that would not cease even after the Korean wars. In the mid-1950s, the U.S. took two steps that directly endangered China's national interests. First, the U.S. continued to provide military support to the Republic of China's (ROC) Chiang Kai-shek government. Moreover, the presence of the U.S. Navy Seventh Fleet was intensified in Taiwan during the Taiwan Straits crisis. Secondly, the U.S. mobilized other countries under its influence to recognize the Chiang Kai-shek government as the legitimate government of China to the detriment of Mao's communist party (Niu, 2010: p. 52). When China lost its seat in the United Nations from 1950 to 1958, Ethiopia backed Taiwan in the United Nations (Shinn, 2014: p. 150).

China and U.S. would eventually be confronted from different sides in another armed conflict during the Cold War, the Vietnam war. Vietnam, which had been a France possession leading to World War II, would later be annexed to Japan. A facet of a communist group resisted the Japanese and eventually freed the country from the Japanese. However, France had renewed their ambitions for Vietnam. With the support of the U.S., France attacked Vietnam during the second half of the 1940s. In 1950, the Soviet Union and China recognized the Democratic Republic of Vietnam, in the North, as an independent state. While the Western powers recognized the South, which would become the Republic of Vietnam.

Meanwhile, France's confrontations with the communist in the North continued to intensify. In 1954, the communist facet was able to repel the French, and with North Vietnam victorious, a cease-fire was declared. However, Vietnam remained partitioned. Intense conflict between North and South Vietnam broke out, and the peaceful period that the country enjoyed with France's ejection was put to an end. The U.S. offered continued support to the military of Southern Vietnam. However, from early 1965 to late 1972, the United States and its affiliated countries sent troops to southern Vietnam, and the attacks on northern Vietnam were intensified (Li, 2000). 
The effects of the Vietnam war would eventually indirectly pave the way for a more productive diplomatic contact between China and Ethiopia. In the mid-1960s, the outbreak of armed conflict ravaged the Horn of Africa, the Somali Republic claiming south-eastern Ethiopia and north-eastern Kenya and French Somaliland. The support from the U.S. became obsolete to Ethiopia. Two reasons were behind the U.S. reluctance to keep its support to Haile Selassie. One, as already mentioned, was related to the Vietnam war. The U.S. involvement in the Vietnam war was increasingly questioned in Washington. Secondly, American policy planners looked to avoid being closely associated with a regime on the verge of failure (Clapham, 2015: pp. 203-204).

\section{Ethiopia Distancing from the West and Establishment of Diplomatic Ties with China}

For two decades, conflicting ideologies hindered the establishment of formal diplomatic relations between China and Ethiopia. The situation would come to change toward the late 1960s and early 1970s. However, the change happened gradually as, over time, the two parties found common ground to build a positive partnership.

When Britain began to limit its influence over Ethiopia in the 1940s (Henze, 2000: p. 129), Haile Selassie became closer to the U.S.. The United States' interest in Ethiopia began to intensify during the World War II period. In the postwar period, both the United States and Ethiopia shared interests in Eritrea. On Ethiopia's side, Haile Selassie claimed that Eritrea had been stripped from Ethiopia by the Italians, and regaining control over the region was Ethiopia's legitimate right. On the other hand, the U.S. had a Signal Corps operating on a former Italian radio-relay base near Asmara dating from 1943. Partnership with Ethiopia was vital for the U.S. to maintain control over the area (Lyons, 1986: pp. 55-57). In the years that followed, from the mid-1950s to the mid-1960s, the scope of the U.S. and Ethiopia relations would grow to cover political, economic, and military areas. The close relations between the U.S. and Ethiopia did not allow Ethiopia to build ties with China. However, When Zhou Enlai met Haile Selassie at the Bandung's Conference, both parties had an opportunity to relate to where their respective countries stood concerning their ideologies. After the conference, the two countries made some cultural exchanges, but no formal diplomatic relations were established (Meskela \& Zhang, 2009: p. 30).

In 1957, the relationships between the U.S. and Ethiopia were stained when the U.S. government announced that Washington would provide financial assistance to Egypt, Ethiopia's traditional enemy, to build the Aswan Dam (Lyons, 1986: p. 61). Disappointed with the U.S., Haile Selassie gradually began to turn his attention to the communist bloc.

\section{Events Leading to the Formalization of the Sino-Ethiopian Relation in 1970}

In the long run, Premier Zhou Enlai's visit to Ethiopia paved the way for the establishment of Sino-Ethiopia diplomatic relations. While the U.S. and the Soviet 
Union pursued diplomatic relations with African countries to expand their international influence, thus maximizing the impact of the harm caused to each other's interests (see Lefebvre, 1998), China's involvement with African countries was primarily and fundamentally guided by principles of "Peaceful Co-existence" and equal co-existence. However China's engagement with the countries of the Horn caused some concern to Haile Selassie. When the tension broke between Ethiopia and Somalia over the Ogaden region border in 1961, China had already established good relations with Somalia. When Premier Zhou Enlai arrived in Ethiopia on 30 January 1964, Haile Selassie addressed the issue of China's support to Somalia. While the tension in the Somalilands was Ethiopia's main problem, there were also other concerns regarding China's relations with other African countries that were in conflict with Haile Selassie's interest in the region. First, China supported the Eritrean Liberation Front (ELF) that sought independence from Ethiopia (Venkataraman \& Gamora 2009: p. 16). Moreover, Emperor Haile Selassie still depended largely on the U.S.'s military support and feared that Washington would cut all the military support if relations with China were established (Wang, 1998: pp. 188-189). China was also cautious in establishing diplomatic relations with Ethiopia if the diplomatic model adopted by Haile Selassie maintained its dependence on the U.S.. China was engaged in introducing a "Chinese revolutionary model" with its partner countries and "to lead the Marxist-Leninist and communist world" (Venkataraman \& Gamora, 2009). Regarding the situation in Somalia, Premier Zhou Enlai assured Emperor Haile Selassie that the relationship between China and Somalia was not aimed at supporting Somalia's military confrontations against Ethiopia. The visit of the Chinese delegation to Somalia was solely based on "mutual friendship and economic exchanges" (Meskela \& Zhang, 2009: p. 32).

In the years that followed Zhou Enlai's visit to Ethiopia, the relationship between the two countries continued to improve. On 4 December 1970, Ethiopia and China formalized the establishment of diplomatic relations. In the following year, Haile Selassie visited China. During the visit, technical and aid agreements were signed between the two countries (Venkataraman \& Gamora, 2009: p. 16). To a large extent, the Sino-Ethiopia formal diplomatic relations were possible because, in the late 1960s, Ethiopia was able to shake the pressure by the U.S., the influence of the Soviet Union was gradually getting into a decline, and China and Ethiopia found common ground in the struggle against oppression and in the fight to promote peace and equality.

\section{Sino-Ethiopian Relations in a Turbulent Time in Ethiopia}

This section discusses the practical lessons Ethiopia can draw from the history of its relations with China. The past of the Sino-Ethiopia's relations is put in perspective of the current situation Ethiopia finds herself. The first part gives a background of the socio-political transformations in Ethiopia in recent years. The second part highlights how the Western countries' interference in Ethiopia's 
domestic affairs is at odds with the path of "peaceful regional coexistence" and domestic peace Ethiopia aims to achieve. Finally, we briefly present the position of China aimed at the social instabilities in Ethiopia and how China has maintained a positive attitude towards her relations with Ethiopia. China's attitude towards the current situation in Ethiopia underscores China's belief in the sovereignty of Ethiopia and the country's ability to handle her own matters. It is believed that, despite the tumultuous sociopolitical period that Ethiopia is going through, the Sino-Ethiopia relations remain on the right track.

\subsection{Ethiopia's Socio-Political Transformations in Recent Years}

In recent years, the countries of the Horn of Africa, specially Ethiopia, have been going through important political, economic, and social changes (Zhang, 2020). With the Ethiopian People's Revolutionary Democratic Front (EPRDF) ascension to power in 1991, there was a renewed belief that the people would be more involved in the "destiny" of the country by having more access to decision-making and control over resources that had previously been in the hands of a minority elite. The EPRDF came to power committed to carrying threefold fundamental reforms, namely, the "decentralization of the state, with the introduction of a system of 'ethnic' or 'multinational' federalism; democratization of its politics, under a multi-party electoral system; and liberalization of the economy, in a neo-liberal international climate" (Vaughan, 2015: p. 284).

However, since the TPLF, lead by Meles Zenawi, was the brain party for the formation of the EPRDF and had played a leading role in toppling Mengistu, the Tigrayans had the upper hand in all the constitutional matters and had more privileges than people from other regions (see Dibu \& Ahadu, 2020; Temin \& Badwaza, 2019). The people did not have much of a voice in the decision-making process, which remained solely in the state's hands. After Zenawi's death in August 2012, Ethiopia witnessed the first signs of change in the leadership of EPRDF and the country. For the first time in over 20 years, a non-Tigrayan leader was appointed to guide the nation. The Southern Ethiopian People's Democratic Movement (SEDPM) president Hailemariam Desalegn was appointed as Ethiopia's prime minister. However, the hegemony of Tigrayans remained evident in every sphere of political activities. There was a growing belief among the people that Desalegn had not managed to come up with his own policies and visions and that he did not meet the majority of Ethiopian people's expectations on solving the challenges that Ethiopia had been facing for years, among which tribalism was at the center, along with the TPLF one party over-dominance in the EPRDF (Aalen, 2014). Desalegn's incapacity to deal with the socio-political problems further fermented the public's years of rage and frustration.

In 2015 EPRDF won the general elections, and a series of political decisions intensified the dissatisfaction by the masses and culminated in protests that would come to hunt the country mainly from same year onwards. As the pressure mounted in the EPDRF leadership, Desalegn resigned to his post in February 2018. Following this, the parliament elected Abiy Ahmed, the Oromo Democratic Party 
(ODP) leader, as Prime Minister on 2 April 2018 (Van der Beken, 2018).

\subsection{The Current Political Situation in Ethiopia}

During the 1974 revolution taken over by the DERG military junta under the leadership of Colonel Mengistu, Emperor Haile Selassie's reign over Ethiopia came to an end. Mengistu led an authoritarian centralist government based on Marxist ideology. Under the iron fist of the DERG regime, regional nationalist movements began to emerge. TPLF played a key role in the resistance to the regime and later its overthrow in 1991. It was under this background that the EPRDF was formed coupling four ethnic parties: the Tigray People's Liberation Front (TPLF), the ODP, the Amhara National Democratic Movement (ANDM), and the SEDPM (Pellet, 2021: p. 10).

In 2018, Abiy Ahmed's new government initiated a general policy pushing toward distancing the country's politics from ethnic federalism. In December 2019, with the merging of the Afar National Democratic Party (ANDP); Benishangul-Gumuz Democratic Party (BDP); ODP; Amhara Democratic Party (ADP); SEPDM; Somali Democratic Party; Gambela Peoples Democratic Movement (GPDM); and Harari National League (HNL) the Prosperity Party was created. On 26 December 2019 the National Electoral Board of Ethiopia (NEBE) issued a recognition certificate legitimizing the newly merged ruling party. The recognition meant the end of the EPRDF. ${ }^{6}$ Initially, the TPLF had also integrated the newly formed party. However, it would eventually withdraw to later engage the Federal government in an open army conflict from late 2020.

Diverging political visions between the new PM and TPLF ferment the tension between the new and former governments. After Abiy came to power, Addis Ababa took several measures that clashed with the visions of the TPLF. In July 2018, a Peace Agreement (PA) between Ethiopia and Eritrea, ending the tensions that had characterized the relations between the two countries since the 1998-2000 war, was signed. An effort that saw Abiy win the Nobel Peace Prize in 2019.7 Domestically, however, the PA had a different meaning. With the PA, several territories north of Tigray would eventually be unconditionally returned to Eritrea. Later in the same year, the Tigrayan leaders were the target of corruption charges (Pellet, 2021). Tensions between the TPLF and Abiy's government intensified at all rates. In March 2020, taking the outbreak of the COVID 19 pandemic as justification, the federal government postponed Ethiopia's 6th national election initially scheduled for August 2020, a decision deemed unconstitutional by the TPLF, ${ }^{8}$ who saw the postponement as a maneuver to remain in

\footnotetext{
6"The EPRDF Officially Ends; The Prosperity Party Begins," Ezega News, Staff Reporter, December 26, 2019,

https://www.ezega.com/News/NewsDetails/7599/The-EPRDF-Officially-Ends-The-Prosperity-Party -Begins.

${ }^{7}$ Lauren Ploch Blanchard, "Ethiopia's Transition and the Tigray Conflict" Congressional Research Service, September 9, 2021, https://crsreports.congress.gov/product/pdf/R/R46905/4.

${ }^{8}$ Lauren Ploch Blanchard, "Ethiopia's Transition and the Tigray Conflict" Congressional Research Service, September 9, 2021, https://crsreports.congress.gov/product/pdf/R/R46905/4.
} 
power by Abiy Ahmed. The elections still went on to be held in the Tigray region in September 2020. TPLF reported a 98 per cent victory in the popular vote. ${ }^{9}$ However, the federal government questioned the legitimacy of the Tigray elections. The confrontation between Abiy's government and the TPLF culminated in an armed conflict in early November 2020.

\subsection{The Sino-Ethiopian Relations in Ethiopia under Armed Conflict}

The situation in Ethiopia has been gaining increasing attention from the international community. The international opinion regarding Ethiopia's internal conflicts has been divided into two diverging positions. On the one hand, the African Community is optimistic that Ethiopia can resolve its internal affairs peacefully. In November 2020, in a visit to Addis Ababa, the African Union Commission Chairperson's High Representative for the Horn of Africa, Olusegun Obasanjo, said, "I am optimistic that common ground towards a peaceful resolution of the conflict can be secured."10 Obasanjo called for unity on all African leaders and the international community in general and "all people of goodwill" to support the mediation efforts for the situation in Ethiopia.

On the other hand, some countries from the West have been pessimistic regarding the dynamics of the situation in Ethiopia. For example, on November 5, 2021, the U.S. embassy in Ethiopia posted on its official website that "the security environment in Ethiopia is very fluid. We advise U.S. citizens who are in Ethiopia to leave the country as soon as possible."11 Moreover, the embassy offered assistance in obtaining air travel from Bole International Airport to all American citizens. On November 6, 2021, news by CNN reported that Oromo Liberation Army (OLA) spokesperson Odaa Tarbii had told CNN that joint rebel fighters were "weeks to months" 12 away from reaching the capital. Taking the TPLF and OLF statements, the international media spread the news that Addis Ababa was under eminent TPLF's siege. ${ }^{13}$ The federal government denied that Addis Ababa was on the verge of a collapse to the TPLF forces.

However, on November 23, the U.S. embassy posted another warning to the Americans in Ethiopia. The Embassy official website released news stating that

\footnotetext{
9"Understanding the conflict in Tigray," Africa Center, November 11, 2020 https://www.atlanticcouncil.org/blogs/africasource/experts-react-understanding-the-conflict-in-tigr ayl.

10“AU envoy says optimistic over peaceful resolution of Ethiopian conflict." Xinhua, November 14, 2021, http://www.news.cn/english/africa/2021-11/14/c_1310310238.htm.

11 "Security Alert: Commercial Air Availability from Addis Ababa," The U.S. Embassy in Ethiopia, November 5, 2021,

https://et.usembassy.gov/security-alert-commercial-air-availability-from-addis-ababa-110521/.

${ }^{12}$ David McKenzie, "Ethiopia's military calls on former members to rejoin army as rebels advance on capital," CNN, November 6, 2021,

https://edition.cnn.com/2021/11/06/africa/ethiopia-military-volunteers-rebel-advance-intl/index.ht $\underline{\mathrm{ml}}$.

${ }^{13}$ Sisay Sahlu "Ethiopia calls evacuation of foreign nationals a psychological warfare," The Reporter November 13, 2021,

https://www.thereporterethiopia.com/article/ethiopia-calls-evacuation-foreign-nationals-psycholog ical-warfare.
} 
"terrorists may attack with little or no warning, targeting diplomatic facilities, tourist locations, transportation hubs (...) western businesses, restaurants, resorts, local government facilities, and other public areas. U.S. citizens are strongly encouraged to maintain a high level of vigilance and avoid areas frequented by foreigners." ${ }^{14}$ A day later, on November 24, the Commonwealth \& Development Office released a piece of news “...urging all British Nationals (...) to leave immediately, while commercial flights are readily available and Addis Ababa Bole International Airport remains open." ${ }^{\prime 15}$ The Ethiopian government repudiated the posture of the foreign embassies in Ethiopia, accusing them of waging psychological warfare against Ethiopia and plotting to ruin the stability of the state. A spokesman of the Ministry of Foreign Affairs, Dina Mufti stated that the calls for evacuation "are either a deliberate attempt to put pressure on the Ethiopian government or a misunderstanding of the existing situation in the country." Dina characterized the act as "an extension of the recent international media campaign against Ethiopia."16

The current situation has not changed China's policy toward Ethiopia. As the pressure on Addis Ababa to resolve Ethiopia's internal conflicts increases, China has come to acknowledge the capacity of the current leadership in Ethiopia to settle their own domestic matters. On December 1, 2021, China's State Councilor and Foreign Minister (FM) Wang Yi met with Ethiopian Deputy Prime Minister and Foreign Minister Demeke Mekonnen in Addis Ababa. The meeting came after China's $8^{\text {th }}$ Ministerial Conference of the Forum on China-Africa Cooperation. ${ }^{17}$ On the same occasion, China's FM reiterated that external factors or domestic change would not affect the bilateral relations between China and Ethiopia. Adding that Beijing would continue to pursue its policy of non-interference, and it opposes the intervention by other countries in Ethiopia's internal affairs. China respects Ethiopia's sovereignty.

More than half a century later, China, with its "non-interference," still represents a partner that African countries in general, and Ethiopia in particular, especially in the period where the country finds herself, cannot overlook. There is a good prospect of steady development of Sino-Ethiopian relations. The efforts by both parties suggest that the bilateral relation between China and Ethiopia will continue to bloom, while the future of the relation between Addis Ababa and the West in a post-conflict Ethiopia remains uncertain.

\footnotetext{
14"Security Alert - U.S. Embassy, Addis Ababa, Ethiopia: Continued Threat of Terrorist Attacks in Ethiopia” The website of the U.S. Embassy in Ethiopia, November 23, 2021, https://et.usembassy.gov/security-alert-u-s-embassy-addis-ababa-ethiopia-5/.

${ }^{15}$ "The FCDO is urging British nationals to leave Ethiopia immediately in light of the deteriorating conflict," Foreign, Commonwealth \& Development Office, November 24, 2021, https://www.gov.uk/government/news/government-urges-british-nationals-to-leave-ethiopia-now. ${ }^{16}$ Sisay Sahlu "Ethiopia calls evacuation of foreign nationals a psychological warfare," The Reporter November 13, 2021,

https://www.thereporterethiopia.com/article/ethiopia-calls-evacuation-foreign-nationals-psycholog ical-warfare.

17“Chinese FM meets with Ethiopian Deputy PM” Xinhua, December 2, 2021, http://english.www.gov.cn/statecouncil/wangyi/202112/03/content WS61a96b6fc6d0df57f98e5f6d. $\underline{\text { html. }}$
} 


\section{Conclusion}

After the foundation of the PRC, for nearly two decades, the ideological differences between China and Ethiopia posed barriers for the two countries to find common ground and establish fruitful diplomatic relations. However, in recent years China and Ethiopia have managed to forge strong diplomatic relations, the results of which are making a great impact not only in Ethiopia but in the whole Africa. A systematic analysis of the evolution of the Sino-Ethiopian relations during the 1950s to the late 1960s shows that unlike many African countries looking to build a new identity in their international relationships, Ethiopia under Haile Selassie government had already solidified its place at the international level. While China and other African countries had fundamentally forged their relations of principles of mutual friendship and brotherliness to fight a common "enemy," the imperialists, at first such ideals were not appealing to Addis Ababa.

While the ideals of the liberation of African countries, values of equality, and freedom sounded laud in the Haile Selassie government, the Emperor had always looked at the situation at the Horn differently compared to other parts of Africa. When China intensified its relations with Africa, Haile Selassie saw Ethiopia's interests threatened. China's relations with the countries in the Horn and Ethiopia's relations with the U.S. were the invisible hand that impeded both countries from engaging in productive bilateral relations from the 1950s to the late 1960s.

This article has provided a detailed description of the background against which Ethiopia and China found themselves when China shifted its diplomatic agenda to intensifying its relations with African countries. Recently many works in the relevant literature have shed increasing light on the dynamics of Sino-Ethiopian relations. However, the focus has largely been on the period after 1970s, giving little attention to how the events leading to the formal establishment of formal Sino-Ethiopian relations unfolded. The period analyzed in this study gives important lessons to both Ethiopia and China, in that while the partnership between Ethiopia and the West was characterized by setbacks and various periods of stalemate when the Ethiopians turned to China, the country started taking significant steps for the development, as can be witnessed today. Moreover, the positive achievements in Sino-Ethiopian relations underscore the importance of dialogue and mutual understanding between nations. When both Ethiopia and China opened themselves to dialogue and understanding each other's position, they made important breakthroughs and found common ground to build fruitful diplomatic relations.

\section{Conflicts of Interest}

The author declares no conflicts of interest regarding the publication of this paper.

\section{References}

Aalen, L. (2014). Ethiopia after Meles: Stability for How Long? Current History, 113, 
192-196. https://doi.org/10.1525/curh.2014.113.763.192

Adunbi, O., \& Stein, H. (2019). The Political Economy of China's Investment in Nigeria: Prometheus or Leviathan? In A. O., \& J. Y. Lin (Eds.), China-Africa and an Economic Transformation (pp. 192-215). Oxford University Press. https://doi.org/10.1093/oso/9780198830504.003.0010

Agyeman, O. (1992). Nkrumah's Ghana and East Africa. Associated University Presses.

Birmingham, D. (1998). Kwame Nkrumah: The Father of African Nationalism. Ohio University Press.

Chemane, V. A. (2019). Mozambique-China Partnership: Crossing "Seeking” Strategies in the Context of Financial Globalization (a Look at the Results of the 2001-2016 Period). Revista Conjuntura Austral, Porto Alegre, 10, 62-80. https://doi.org/10.22456/2178-8839.87743

Chen, J. (2019). From Mao to Deng: China's Changing Relations with the United States. CWIHP Working Paper No. 92, Cold War International History Project. https://www.wilsoncenter.org/publication/mao-to-deng-chinas-changing-relations-the -united-states

Clapham, C. (2015). The Era of Haile Selassie. In G. Prunier, \& É. Ficquet (Eds.), Understanding Contemporary Ethiopia: Monarchy, Revolution and the Legacy of Meles Zenawi (pp. 183-207). Hurst.

Dibu, W., \& Ahadu, E. (2020). Post-2018 Political Reforms in Ethiopia: Its Achievements and Challenges. An International Review of the Humanities and Social Science, 11, 439-451.

Hanauer, L., \& Morris L. J. (2014). Chinese Engagement in Africa: Drivers, Reactions, and Implications for US Policy. Rand Corporation.

Henze, P. (2000). Layers of Time: A History of Ethiopia. Palgrave. https://doi.org/10.1007/978-1-137-11786-1

Jabulani, C. B. (2002). Rolihlahla Dalibhunga Nelson Mandela: An Ecological Study. Trafford on Demand.

Leake, G. A. (2020). China's Engagement in the Promotion of Peace and Security in the Horn of Africa: An Interplay of Big Power Responsibility and Geopolitical Interest. African Journal of Political Science and International Relations, 14, 150-158. https://doi.org/10.5897/AJPSIR2019.1173

Lefebvre, J. (1998). The United States, Ethiopia and the 1963 Somali-Soviet Arms Deal: Containment and the Balance of Power Dilemma in the Horn of Africa. The Journal of Modern African Studies, 36, 611-643. https://doi.org/10.1017/S0022278X98002870

Li, D. (2000). The Sino-Soviet Clashes and Conflicts over the Aid Vietnam Resist America's Issue (1965-1972) (Part 1). Contemporary China History Studies, No. 4, 44-57.

Li, M. (2011). Ideological Dilemma: Mao's China and the Sino-Soviet Split, 1962-63. Cold War History, 11, 387-419. https://doi.org/10.1080/14682745.2010.498822

Liao, X. (2013). Two Milestones of the Opening and Development of Sino-African Relations-The Historical Contribution by Zhou Enlai. Literature of Chinese Communist Party, No. 2, 39-49.

Luan, J. (2007). An Analysis of the Motives behind the Deterioration of the Sino-Soviet Relations. Contemporary China History Studies, No. 6, 33-44.

Lyons, T. (1986). The United States and Ethiopia: The Politics of a Patron-Client Relationship. Northeast African Studies, 8, 53-75.

Meskela, D. K., \& Zhang, Y. (2009). Evolving of China-Ethiopia Diplomatic Relations 
(1949-1970). West Asia and Africa, 5, 29-32.

Muekalia, D. J. (2004). Africa and China's Strategic Partnership. African Security Review, 13, 5-11. https://doi.org/10.1080/10246029.2004.9627264

Niu, J. (2005). 1962: The Eve of the Left Turn in China's Foreign Policy. CWIHP Working Paper No. 48, Cold War International History Project.

https://www.wilsoncenter.org/sites/default/files/media/documents/publication/NiuJun WP481.pdf

Niu, J. (2010). Introduction to History of Foreign Relations of the People's Republic of China (1949-2000). Peking University Press.

Niu, Z. (2018). A Historical Overview of China-UN Relations. Journal of Asia-Pacific Studies, 30, 65-76.

Pellet, P. (2021). Understanding the 2020-2021 Tigray Conflict in Ethiopia-Background, Root Causes, and Consequences. KKI Elemzések, 39, 1-20.

Shinn, D. H. (2005). China's Approach to East, North and the Horn of Africa, Testimony before the U.S.-China Economic and Security Review Commission China's Global Influence: Objectives and Strategies. https://www.uscc.gov/sites/default/files/7.21-22.05shinn david wrts.pdf

Shinn, D. H. (2014). Ethiopia and China: Two Former Empires Connect in the 20th Century. International Journal of Ethiopian Studies, 8, 149-164.

Temin, J., \& Badwaza, Y. (2019). Aspirations and Realities in Africa: Ethiopia's Quiet Revolution. Journal of Democracy, 30, 139-153. https://doi.org/10.1353/jod.2019.0048

Traoré, S. (2021). The Strategy of China in Sino-African Relations. Open Journal of Political Science, 11, 614-629. https://doi.org/10.4236/ojps.2021.114039

Van der Beken, C. (2018). The Challenge of Reform within Ethiopia's Constitutional Order. Rift Valley Institute (Briefing Paper).

https://riftvalley.net/publication/challenge-reform-within-ethiopias-constitutional-ord $\underline{\mathrm{er}}$

Vaughan, S. (2015). Federalism, Revolutionary Democracy and the Developmental State. In G. Prunier, \& É. Ficquet (Eds.), Understanding Contemporary Ethiopia: Monarchy, Revolution and the Legacy of Meles Zenawi (pp. 283-312). Hurst.

Venkataraman, M., \& Gamora, G. (2009). An Analysis of China-Ethiopia Relations during the Cold War. China Report, 45, 7-22.

https://doi.org/10.1177/000944550904500102

Wang, T. (1998). The History of the Diplomatic Relations of People's Republic of China (Vol. 2). World Knowledge Publishing House.

Yang, K. (2003). Mao Zedong and the Two Taiwan-Strait Crises. Journal of Historical Science, 11, 52-59.

Zhang, C. (2020). Regional Transformation of the Horn of Africa: Implications for BRI Implementation. China Quarterly of International Strategic Studies, 6, 288-309. https://doi.org/10.1142/S2377740020500190 